\section{Ганна Бойко, Олена Носовець, Свген Настенко}

\title{
Алгоритм оцінки фізичного стану студентів за функціональними патернами системи кровообігу
}

Розроблено методику оцінювання індивідуальних особливостей кровообігу, яка дає змогу виявити осіб із підвищеним ризиком раптових порушень гемодинаміки, здійснювати контроль рівня функціональної тренованості студентів. Виявлено вісім функціональних патернів реакції системи кровообігу на фізичне навантаження.

Ключові слова: функціональна проба, адаптаційні порушення, гемодинаміка, студенти, методика оцінки.

Постановка наукової проблеми та їі значення. Одна 3 актуальних проблем системи фізичного виховання - підвищення ефективності навчального процесу у вищих навчальних закладах за рахунок удосконалення методичної бази. При побудові навчальних програм потрібно враховувати індивідуальні особливості фізичного розвитку й функціональної тренованості студентів.

Однак складання програм із фізичного виховання ускладнене повною відсутністю відомостей про стан здоров’я студентів. Зокрема, у 2015 р. скасовано медичні форми №086-У, що подавалися при вступі до ВН3, а графік медогляду у вищих навчальних закладах розтягнуто на піврічний період або він і зовсім відсутній.

Як і раніше, актуальним залишається використання експрес-методів оцінювання стану здоров’я студентів (проби Мартіне, Гарвардський степ-тест, методика Р. М. Баєвського, Г. Л. Апанасенка, методи контролю з включенням антропометричних методик, рухових тестів тощо).

Такі методики надають базові відомості про фізичний розвиток студентів, але не дозволяють оцінювати поточний стан і прогнозувати розвиток негативних реакцій на навантаження.

Останнім часом збільшилася кількість випадків різкого погіршення самопочуття в студентів на заняттях із фізичного виховання, відомо про наявність смертельних випадків [1, с. 161-162; 2].

У НТУУ «КПІ» впроваджено секційну форму занять із фізичного виховання [3, с. 50-55]. Проводяться заняття 315 видів спорту й рухової активності, що вибираються студентами за власним бажанням без урахування рівня функціональної тренованості [4, с. 94-99]. Перед викладачами кожного навчального відділення стоїть завдання вибору оптимальної програми тренувальних впливів.

Аналіз досліджень цієї проблеми. У літературі широко представлено роботи з оцінки фізичного стану студентів [5, с. 264-274; 6; 7, с. 22-28], проаналізовано час відновлення після навантажень. Широко використовується індекс Робінсона, що відображає енерговитрати міокарда, однак не характеризує умови їх відновлення. Поряд із цим практично відсутні дослідження, що враховують динаміку показників стану організму й окремих його систем у часі, тобто функціональні патерни реакції на навантаження. Відомі методи оцінки [8; 9; 10, с. 15-37] не дають змоги виявити граничні стани, діагностувати наявність патологічних процесів [11; 12, с. 156-162].

Мета й завдання статті. Мета роботи - створення методики оцінки функціонального стану серцево-судинної системи для виявлення груп зі зниженим адаптаційним потенціалом.

Дослідження проводили на базі НТУУ «КПІ» у лабораторії функціональних резервів кафедри фізичного виховання. Після пояснення мети дослідження, характеру процедур, потенційного ризику роботи студенти давали свою письмову згоду на участь у дослідженні. Усі експериментальні процедури схвалено Комісією з біоетики (протокол № 1 від 1.09.15).

У дослідженнях узяли участь 1107 студентів, які пройшли медичний контроль і були допущені за станом здоров'я до занять із фізичного виховання. 3 них - 485 дівчат і 622 юнаків віком 17-20 років $(18 \pm 0,6)$.

Використано модифіковану методику проведення навантажувальної проби Мартіне - 20 присідань за 30 с. Артеріальний тиск, а також частоту серцевих скорочень реєстрували до початку проби й кожну наступну хвилину після проби до повернення цих показників до вихідного рівня. Дані фіксували цифровим осцилометричним тонометром А \& D UA787.

Додатково в стані спокою реєстрували 140 показників, що характеризують антропометричні особливості, особливості кровоносної, нервової, дихальної систем. Для оцінки адаптаційного потенціалу та рівня індивідуального здоров’я застосовано методики Р. М. Баєвського, Г. Л. Апанасенка [13-15].

(С Бойко Г., Носовецьь О., Настенко С., 2015 
Виклад основного матеріалу й обгрунтування отриманих результатів дослідження. У результаті аналізу адаптаційного потенціалу за методикою Р. М. Баєвського встановлено, що серед 1107 обстежених студентів у $55 \%$ простежено напругу механізмів адаптації, у $29 \%$ ії визнано незадовільною, у $6 \%$ - відзначено зрив адаптації. Отже, 90 \% студентів мали відхилення в стані здоров’я.

Під час оцінювання рівня індивідуального здоров'я (РІЗ) за методикою Г. Л. Апанасенка встановлено, що в зазначеній групі 30 \% студентів мали РІЗ нижчий від середнього, $61 \%$ - низький, що в сумі складає $91 \%$ від кількості обстежених.

Аналіз даних за методикою Г. Л. Апанасенка засвідчив, що отримані несприятливі результати зумовлені патологічними відхиленнями індексу Робінсона (подвійний добуток), часом відновлення частоти пульсу й силового індексу. Два з трьох зазначених показників відображають стан системи кровообігу, але не дають змоги виявити регуляторні особливості останньої.

Для уточнення індивідуальних особливостей кровообігу використано методику на основі проби Мартіне з модифікаціями, зазначеними вище. Застосування кластерізаційного алгоритму «k-середніх» на даних вимірювань частоти пульсу й артеріального тиску дало змогу виокремити вісім кластерів (функціональних патернів реакції на фізичне навантаження), що найбільш відрізнялися один від одного за величинами та динамікою показників артеріального тиску й частоти пульсу.

На рис. 1 представлено динаміку пульсу (а), систолічного (б) та діастолічного (в) артеріального тиску всередині кожного кластера до проби й у наступні 5 хв після ії припинення. Останні можна розглядати як функціональні патерни реакції системи кровообігу $(\mathrm{CK})$ на фізичне навантаження.

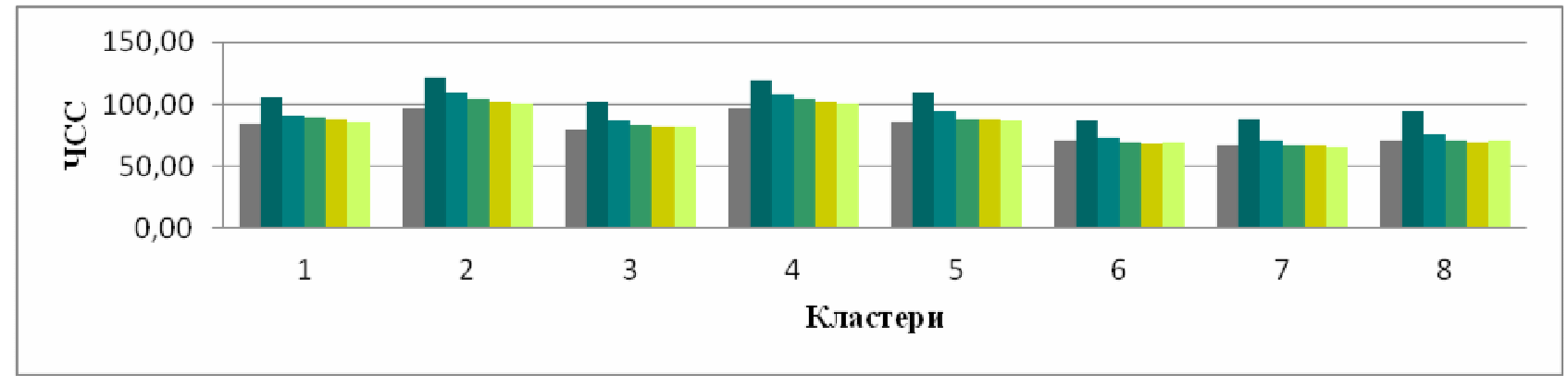

$a$
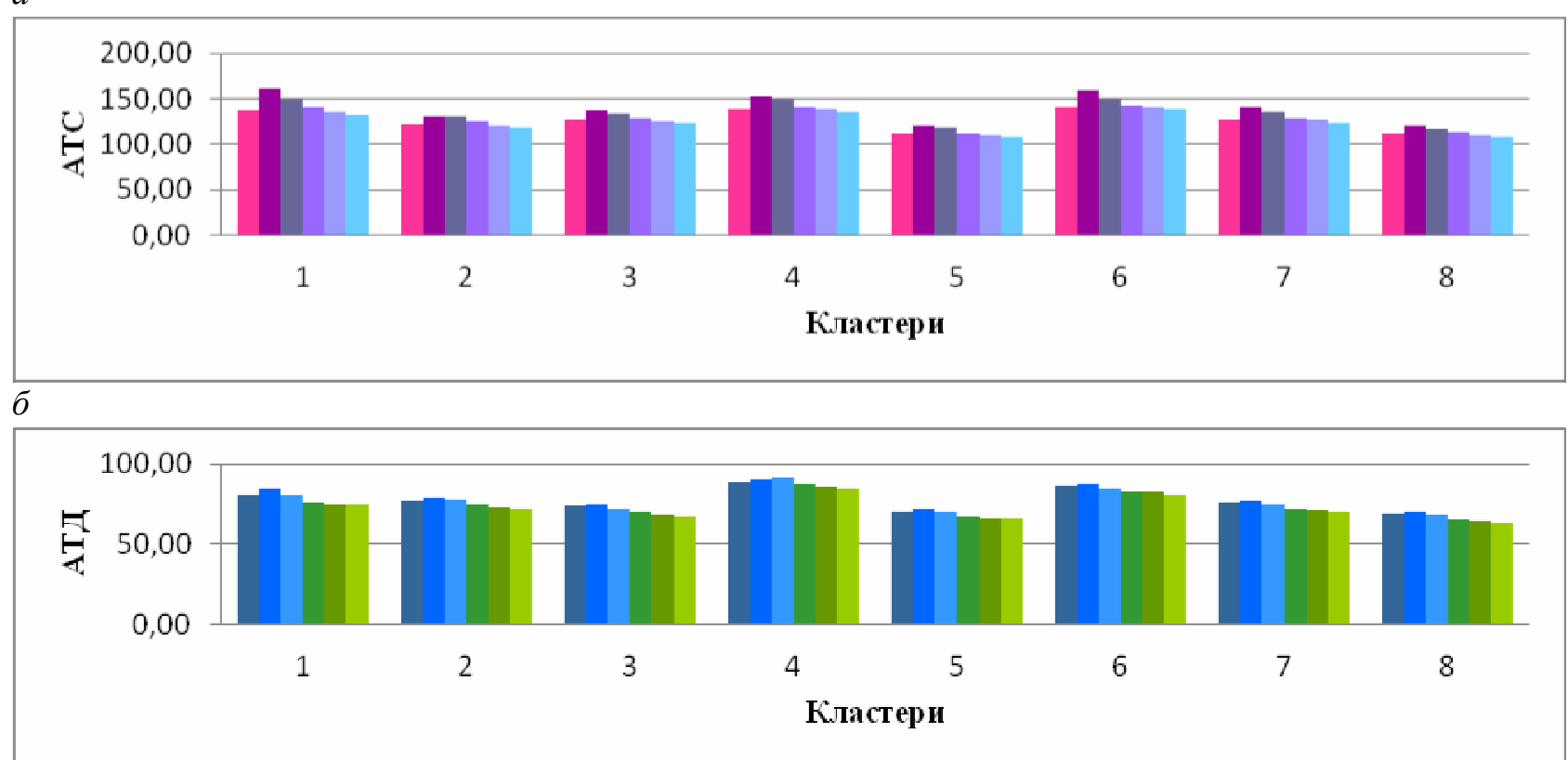

B

Рис. 1. Функціональні патерни реакиї пульсу (а), систолічного (АТС) (б) і діастолічного (АТД) (в) артеріального тиску

Примітка. Показана динаміка зміни показників у різні періоди часу до й після навантаження. Модифікована проба Мартіне. 
Статистичні характеристики пульсу, систолічного й діастолічного артеріального тиску наведено в табл. $1-3$.

Максимальні значення систолічного і діастолічного артеріального тиску спостерігались у кластерах 1, 4 і 6 (рис. 1б), (табл. 2; 3).

Найбільші значення частоти пульсу на етапах виконання проби були в кластерах 2, 4, 5 та 1 (рис. 1а, табл. 1).

Таблиия 1

Динаміка частоти серцевих скорочень, $y \partial / x \boldsymbol{~}$, на етапах модифікованої проби Мартіне $(M \pm S D)$

\begin{tabular}{|l|l|l|l|l|l|l|l|l|}
\hline \multicolumn{1}{|c|}{$\begin{array}{c}\text { Фаза } \\
\text { вимірювання }\end{array}$} & $\begin{array}{c}\mathbf{1} \text { кластер } \\
(\mathbf{n = 1 0 3})\end{array}$ & $\begin{array}{c}\mathbf{2} \text { кластер } \\
(\mathbf{n = 1 8 9})\end{array}$ & $\begin{array}{c}\mathbf{3} \text { кластер } \\
(\mathbf{n = 1 9 9 )}\end{array}$ & $\begin{array}{c}\mathbf{4} \text { кластер } \\
(\mathbf{n = 6 1})\end{array}$ & $\begin{array}{c}\mathbf{5} \text { кластер } \\
(\mathbf{n = 2 0 2})\end{array}$ & $\begin{array}{c}\mathbf{6} \text { кластер } \\
(\mathbf{n = 3 3})\end{array}$ & $\begin{array}{c}\mathbf{7} \text { кластер } \\
(\mathbf{n = 1 3 1})\end{array}$ & $\begin{array}{c}\mathbf{8} \text { кластер } \\
(\mathbf{n = 1 8 9})\end{array}$ \\
\hline У спокої & $84 \pm 8$ & $97 \pm 10$ & $79 \pm 8$ & $97 \pm 11$ & $85 \pm 8$ & $71 \pm 10$ & $66 \pm 8$ & $71 \pm 7$ \\
\hline $\begin{array}{l}\text { На 1 хв } \\
\text { відновлення }\end{array}$ & $105 \pm 9$ & $121 \pm 11$ & $102 \pm 11$ & $119 \pm 12$ & $109 \pm 10$ & $86 \pm 14$ & $88 \pm 12$ & $95 \pm 11$ \\
\hline $\begin{array}{l}\text { На 2 хв } \\
\text { відновлення }\end{array}$ & $91 \pm 9$ & $109 \pm 10$ & $87 \pm 9$ & $107 \pm 12$ & $94 \pm 9$ & $73 \pm 12$ & $70 \pm 9$ & $76 \pm 9$ \\
\hline $\begin{array}{l}\text { На 3 хв } \\
\text { відновлення }\end{array}$ & $89 \pm 9$ & $104 \pm 10$ & $83 \pm 9$ & $104 \pm 11$ & $89 \pm 8$ & $70 \pm 9$ & $67 \pm 8$ & $70 \pm 8$ \\
\hline $\begin{array}{l}\text { На 4 хв } \\
\text { відновлення }\end{array}$ & $88 \pm 9$ & $102 \pm 11$ & $82 \pm 9$ & $102 \pm 11$ & $88 \pm 8$ & $68 \pm 7$ & $66 \pm 9$ & $69 \pm 8$ \\
\hline $\begin{array}{l}\text { На 5 хв } \\
\text { відновлення }\end{array}$ & $85 \pm 8$ & $101 \pm 11$ & $82 \pm 9$ & $101 \pm 10$ & $87 \pm 8$ & $69 \pm 8$ & $65 \pm 7$ & $70 \pm 7$ \\
\hline
\end{tabular}

Таблиия 2

Динаміка систолічного артеріального тиску на етапах модифікованої проби Мартіне $(M \pm S D), \boldsymbol{M м} \mathrm{pm} . \mathrm{cm}$.

\begin{tabular}{|c|c|c|c|c|c|c|c|c|}
\hline $\begin{array}{c}\text { Фаза } \\
\text { вимірювання }\end{array}$ & $\begin{array}{c}1 \text { кластер } \\
(\mathbf{n}=\mathbf{1 0 3})\end{array}$ & $\begin{array}{c}2 \text { кластер } \\
(\mathbf{n}=89)\end{array}$ & $\begin{array}{c}3 \text { кластер } \\
(\mathbf{n}=199)\end{array}$ & $\begin{array}{c}4 \text { кластер } \\
(\mathrm{n}=61)\end{array}$ & 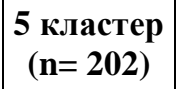 & 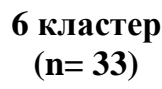 & $\begin{array}{c}7 \text { кластер } \\
\text { (n= 131) }\end{array}$ & $\begin{array}{c}8 \text { кластер } \\
(\mathbf{n}=189)\end{array}$ \\
\hline У спокої & $137 \pm 9$ & $122 \pm 9$ & $127 \pm 9$ & $139 \pm 14$ & $112 \pm 9$ & $141 \pm 13$ & $127 \pm 9$ & $111 \pm 9$ \\
\hline $\begin{array}{l}\text { На } 1 \text { хв } \\
\text { відновлення }\end{array}$ & $161 \pm 17$ & $130 \pm 12$ & $138 \pm 12$ & $152 \pm 21$ & $120 \pm 10$ & $159 \pm 21$ & $141 \pm 13$ & $120 \pm 11$ \\
\hline $\begin{array}{l}\text { На } 2 \text { хв } \\
\text { відновлення }\end{array}$ & $149 \pm 12$ & $130 \pm 9$ & $134 \pm 7$ & $150 \pm 15$ & $118 \pm 9$ & $150 \pm 17$ & $136 \pm 10$ & $117 \pm 8$ \\
\hline $\begin{array}{l}\text { На } 3 \text { хв } \\
\text { відновлення }\end{array}$ & $140 \pm 10$ & $125 \pm 9$ & $129 \pm 7$ & $141 \pm 12$ & $112 \pm 8$ & $142 \pm 12$ & $129 \pm 9$ & $113 \pm 7$ \\
\hline $\begin{array}{l}\text { На } 4 \text { хв } \\
\text { відновлення }\end{array}$ & $135 \pm 9$ & $120 \pm 8$ & $126 \pm 7$ & $138 \pm 11$ & $110 \pm 7$ & $141 \pm 13$ & $127 \pm 8$ & $110 \pm 7$ \\
\hline $\begin{array}{l}\text { На } 5 \text { хв } \\
\text { відновлення }\end{array}$ & $132 \pm 9$ & $118 \pm 8$ & $123 \pm 6$ & $135 \pm 13$ & $108 \pm 7$ & $138 \pm 13$ & $124 \pm 8$ & $108 \pm 8$ \\
\hline
\end{tabular}

Для інтерпретації особливостей зміни гемодинаміки в представників кожної з восьми груп (кластерів) використано процентільні діаграми ЧСС - АТС і ЧСС - АТД (рис. 2; 3) [16, с. 51-54; 17, с. 235-240]. 
Динаміка діастолічного артеріального тиску на етапах модифікованої проби Мартіне

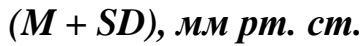

\begin{tabular}{|l|l|l|l|l|l|l|l|l|}
\hline $\begin{array}{c}\text { Фаза } \\
\text { вимірювання }\end{array}$ & $\begin{array}{c}\text { 1 кластер } \\
(\mathbf{n = 1 0 3})\end{array}$ & $\begin{array}{c}\text { 2 кластер } \\
(\mathbf{n = 1 8 9})\end{array}$ & $\begin{array}{c}\mathbf{3} \text { кластер } \\
(\mathbf{n = 1 9 9 )}\end{array}$ & $\begin{array}{c}\text { 4 кластер } \\
(\mathbf{n = 6 1})\end{array}$ & $\begin{array}{c}\mathbf{5} \text { кластер } \\
(\mathbf{n = 2 0 2})\end{array}$ & $\begin{array}{c}\mathbf{6} \text { кластер } \\
(\mathbf{n = 3 3})\end{array}$ & $\begin{array}{c}7 \text { кластер } \\
(\mathbf{n = 1 3 1})\end{array}$ & $\begin{array}{c}\mathbf{8} \text { кластер } \\
(\mathbf{n = 1 8 9})\end{array}$ \\
\hline У спокої & $81 \pm 6$ & $77 \pm 6$ & $74 \pm 7$ & $88 \pm 8$ & $70 \pm 7$ & $86 \pm 8$ & $76 \pm 6$ & $69 \pm 6$ \\
\hline $\begin{array}{l}\text { На 1 хв } \\
\text { відновлення }\end{array}$ & $85 \pm 9$ & $79 \pm 8$ & $75 \pm 9$ & $90 \pm 9$ & $72 \pm 9$ & $87 \pm 9$ & $76 \pm 7$ & $70 \pm 8$ \\
\hline $\begin{array}{l}\text { На 2 хв } \\
\text { відновлення }\end{array}$ & $80 \pm 8$ & $78 \pm 7$ & $72 \pm 7$ & $91 \pm 7$ & $70 \pm 7$ & $84 \pm 7$ & $74 \pm 7$ & $68, \pm 7$ \\
\hline $\begin{array}{l}\text { На 3 хв } \\
\text { відновлення }\end{array}$ & $76 \pm 7$ & $75 \pm 6$ & $70 \pm 7$ & $88 \pm 8$ & $67 \pm 7$ & $83 \pm 8$ & $72 \pm 8$ & $66 \pm 6$ \\
\hline $\begin{array}{l}\text { На 4 хв } \\
\text { відновлення }\end{array}$ & $75 \pm 6$ & $73 \pm 6$ & $68 \pm 7$ & $86 \pm 7$ & $66 \pm 6$ & $83 \pm 9$ & $71 \pm 7$ & $64 \pm 6$ \\
\hline $\begin{array}{l}\text { На 5 хв } \\
\text { відновлення }\end{array}$ & $75 \pm 5$ & $72 \pm 6$ & $67 \pm 7$ & $85 \pm 6$ & $66 \pm 7$ & $80 \pm 8$ & $70 \pm 6$ & $64 \pm 6$ \\
\hline
\end{tabular}

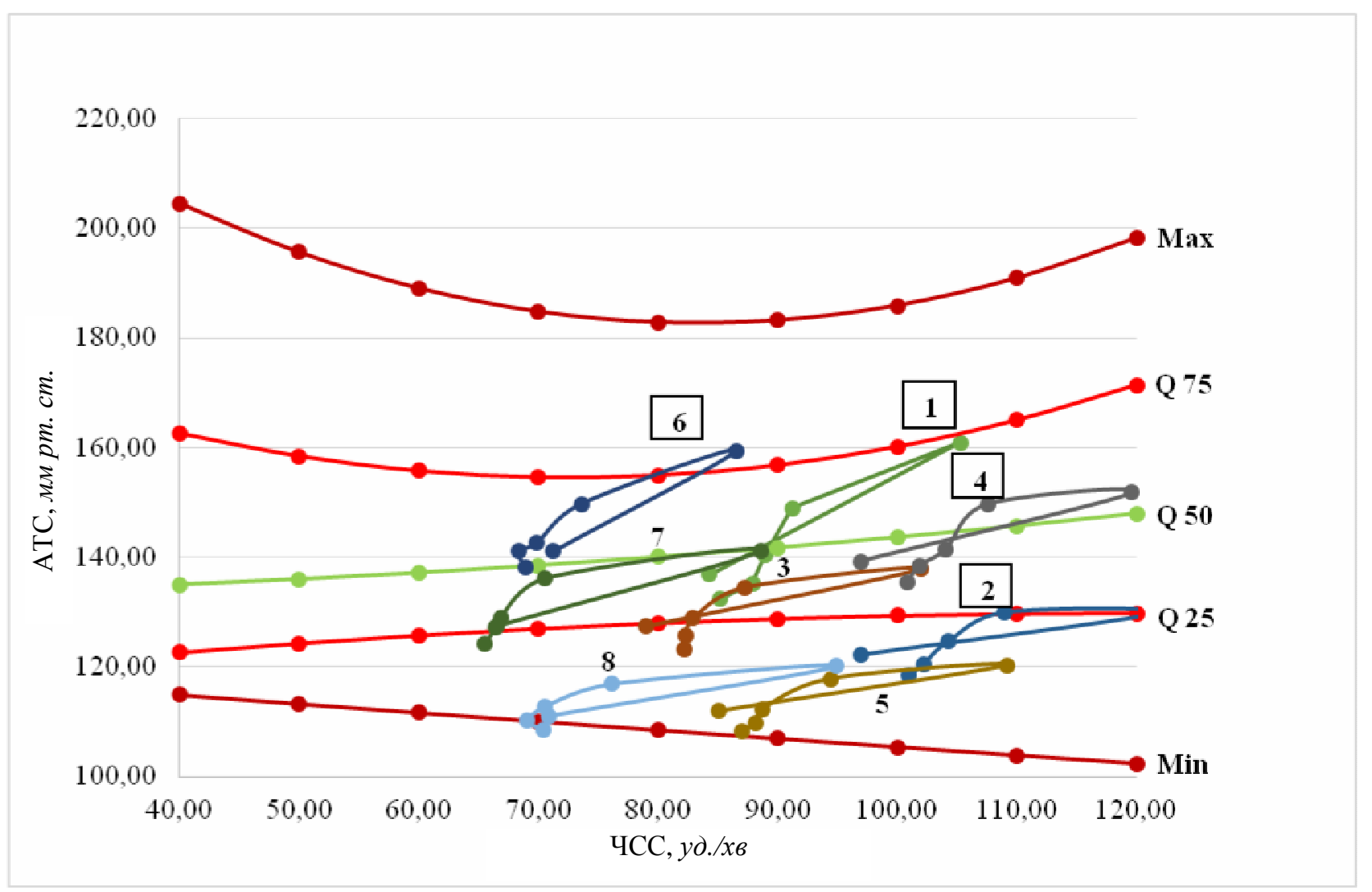

Рис. 2. Модифікована проба Мартіне на процентільній діаграмі ЧСС-АТС. Зверху вказані номери кластерів

Примітка. Виділені номери відповідають несприятливим функціональним патернам (кластерам).

Кожну точку зміни показників представлено у вигляді траєкторії: спокій, $1-5$ хв після навантаження (рис. 2; 3).

Згідно з дослідженнями Шрамека (2002 р.) [18], підтвердженими й нашими попередніми дослідженнями, за частоти серцевих скорочень 120 уд /хв і вище ударний об'єм лівого шлуночка 
досягає граничних (максимальних) значень, що свідчить про граничне навантаження на серце при навантажувальній пробі в кластерах 2, 4, 5 i, відповідно, про знижені функціональні резерви СК у представників цих кластерів (рис. 1).

Реакція на фізичне навантаження в представників кластерів 1 і 6 характеризувалася суттєвим підвищенням АТС, а, отже, - схильністю до артеріальної гіпертензії. Це було підставою для зміни тренувальної програми в представників цих груп, а для деяких - i виду спорту або рухової активності.

Кластери 2 і 4 - характеризувались високою частотою серцевих скорочень, що призводить до скорочення діастоли, і низькими значеннями АТД, що в сукупності свідчить про погіршення умов коронарного кровопостачання й про досягнення максимальних значень ударного об'єму лівого шлуночка під час навантажувальної проби (рис. 2; 3).

Динаміка показників у групах, що відповідали кластерам 3, 7 і 8, свідчила про задовільний адаптаційний потенціал серця студентів цих груп.

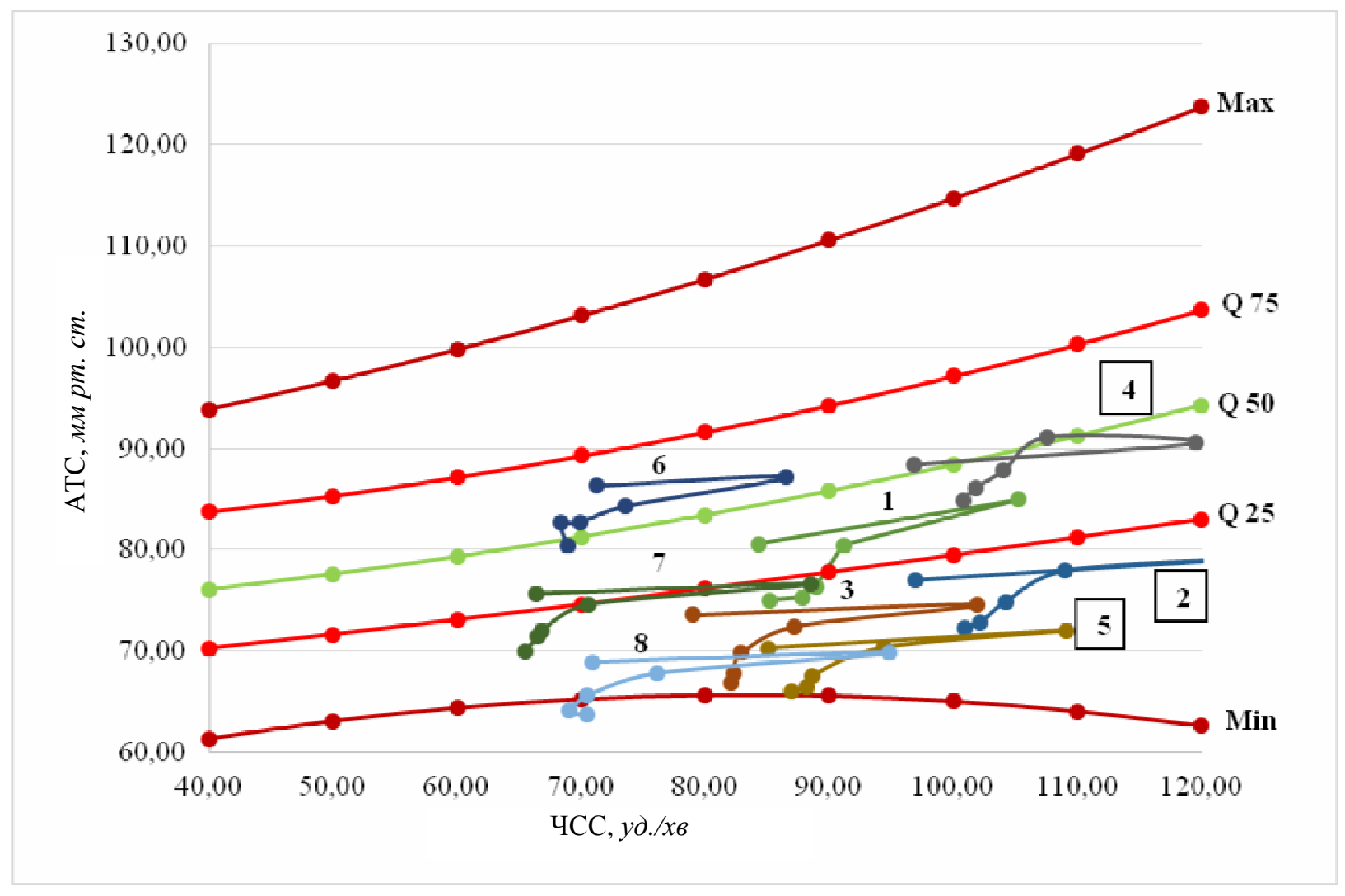

Рис. 3. Модифікована проба Мартіне на прочентільній діаграмі ЧСС-АТД. Зверху вказані номери кластерів

Примітка. Виділені номери відповідають несприятливим функціональним патернам (кластерам).

Аналіз діаграми ЧСС - АТД (рис. 1-3) показав, що найгірші умови коронарного кровопостачання спостерігались у кластерах $2 ; 4 ; 5$. Із підвищенням ЧСС істотно коротшає діастола (час коронарної перфузії міокарда), що в поєднанні з низьким діастолічним АТ, який є однією 3 характеристик коронарного перфузійного тиску, призводить до погіршення коронарного кровотоку. Кількісною оцінкою умов коронарного кровопостачання, що включає зазначені показники, є індекс життєздатності субендокарда [19], зміни якого будуть детально проаналізовані у наших подальших дослідженнях.

Висновки та перспективи подалышого дослідження. Модифікована проба Мартіне в поєднанні 3 розробленою нами методикою оцінки стану кровообігу продемонструвала високу інформативність для виявлення груп ризику на заняттях із фізичного виховання. 
Розроблена методика дає змогу встановити, що $53 \%$ студентів мали несприятливі реакції на навантажувальну пробу, у тому числі $12 \%$ - схильні до розвитку артеріальної гіпертензії, а $41 \%$ мали знижені адаптаційні резерви системи кровообігу.

Розроблена методика допомагає визначити осіб із підвищеним ризиком раптових порушень гемодинаміки, яким потрібне поглиблене медичне обстеження та (або) обмеження фізичних навантажень.

Методика дає можливість вибирати вид рухової активності, обсяг й інтенсивність навантажень, прийнятних для представників кожної групи, залежно від типу реакції на функціональну пробу.

Подальші дослідження будуть спрямовані на вивчення факторів, які обумовлюють порушення гемодинаміки.

\section{Джерела та література}

1. Faigenbaum A. Pediatric Resistance Training: Benefits, Concerns, and Program Design Considerations / A. Faigenbaum, G. Myer // Current Sports Medicine Reports. - 2010. - № 9. - S. 161-168.

2. McIntosh P. Landmarks in the History of Physical Education / P. McIntosh. - New York ; USA : Routledge, 2013. $-238 \mathrm{~s}$.

3. Вихляєв Ю. М. Особливості форм організації освітнього процесу з фізичного виховання студентів / Ю. М. Вихляєв // Фізична культура, спорт та здоров'я нації. - 2015. - №15. - С. 50-55.

4. Досвід використання новітніх технологій в методичному та організаційному забезпеченні дисципліни фізичне виховання в НТУУ «КПІ» / Д. М. Міщук, Г. Л. Бойко, Л. В. Анікеєнко, Л. В. Єфременко // Педагогіка, психологія та медико-біологічні проблеми фізичного виховання і спорту. - 2010. - № 4. C. 94-99.

5. Hupperta F. A controlled trial of mindfulness training in schools: The importance of practice for an impact on well-being / F. Huppert, D. Johnson // The Journal of Positive Psychology: Dedicated to furthering research and promoting good practice. - 2010. - № 5. - S. 264-274.

6. Winnick J. Adapted Physical Education and Sport / Joseph P. Winnick. - New Zealand : Human Kinetics, 2011. $-656 \mathrm{c}$.

7. Ahn S. A Meta-analysis of the Relationship Between Physical Activity and Mental Health / S. Ahn, A. Fedewa // J. Pediatr. Psychol. - 2011. - №10. - C. 22-28.

8. Forbes H. Physical Examination and Health Assessment / H. Forbes, E. Watt. - Illinois, USA : Saunders, 2011. -665 p.

9. Rhoads J. Advanced Health Assessment and Diagnostic Reasoning / J. Rhoads, S. W. Petersen. - USA: World Headquarters, 2013. $-502 \mathrm{p}$.

10. Kaplan B. Evaluating informatics applications - clinical decision support systems / B. Kaplan // Int J Med Inform. - 2001. - № 64. - P. 15-37.

11. Bruce N. Quantitative Methods for Health Research / N. Bruce, D. Pope, D. Stanistreet. - Liverpool ; UK : Wiley, 2012. $-513 \mathrm{p}$.

12. Пропорция «золотого сечения» во временных и силовых показателях сердечного сокращения в норме и при недостаточности кровообращения / [Г. В. Кнышов, Е. А. Настенко, Б. Л. Палец та ін.] // Щорічник наукових праць Асоціації серцево-судинних хірургів України. - 2001. - № 9. - С. 156-162.

13. Апанасенко Г. Л. Эволюция биоэнергетики и здоровье человека / Г. Л. Апанасенко. - СПб. : Петрополис, 1992. - 137 с.

14. Bioenergy Research: Advances and Applications / G. G.Vijai, M. Tuohy, C. Kubicek, J. Saddler. - Oxford : Elsevier, 2013. $-496 \mathrm{p}$.

15. Баевский Р. М. Прогнозирование состояний на грани нормы и патологии / Р. М. Баевский. - М. : Медицина, 1979. - 298 с.

16. Настенко Е. А. Исследование возрастных и гендерных особенностей артериального давления / Е. А. Настенко, Е. К. Носовец // Восточноевропейский журнал передовых технологий. - 2013. - № 1/2 (61). - C. 51-54.

17. Оцінка стану мікроциркуляторної системи за процентильними діграмами «ЧСС-тиск» у гендероднорідних групах / Г. В. Книшов, Е. А. Настенко, О. К. Носовець, В. В. Шаповалова // Щорічник наукових праць Асоціації серцево-судинних хірургів України. - 2012. - № 20. - С. 235-240.

18. Cannesson M. Perioperative Hemodynamic Monitoring and Goal Directed Therapy / M. Cannesson, R. Pearse. Cambridge ; UK : Cambridge University Press, 2014. - 297 p.

19. Iskandrian A. E. Myocardial Viability / A. E. Iskandrian, E. E. van der Wall. - Vienne : Springer Sience, 2012. - $132 \mathrm{p}$.

Бойко Анна, Носовец Елена, Настенко Евгений. Алгоритм оценки физического состояния студентов по функциональным паттернам системы кровообращения. Цель работы - создание методики оценки 
функционального состояния сердечно-сосудистой системы для выявления групп студентов со сниженным адаптационным потенциалом. В исследованиях приняло участие 1107 студентов. Из них - 485 девушек, 622 юноши в возрасте 17- 20 лет. Проведена оценка индивидуального здоровья студентов по методике Р. М. Баевского, Г. Л. Апанасенко. На основе пробы Мартине с модификациями разработана методика оценки индивидуальных особенностей кровообращения, позволяющая выявить характер адаптационных нарушений. Выявлено восемь функциональных паттернов реакции системы кровообращения на физическую нагрузку. Разработанная методика позволяет определить лиц с повышенным риском внезапных нарушений гемодинамики, осуществлять контроль уровня функциональной тренированности студентов, подбирать индивидуальные программы физических нагрузок.

Ключевые слова: функциональная проба, адаптационные нарушения, гемодинамика, студенты, методика оценки.

Boyko Anna, Nosovets Olena, Nastenko Evgenii. Algorithm of Assessment of Physical Condition of Students with Functional Patterns of Circulatory System. Objective of work - forming of method of estimation of circulatory system functional states to reveal groups of students with reduced adaptational potential. Materials: 1107 students took part in disquisition. There were 485 girls and 622 boys at the age from 17 to 20 years. Estimation of individual health of students according to the methods of R. M. Baevski and G. L. Apanasenko has been carried out. Methods are based on Martine's test with modifications for assessment of individual peculiarities of circulation, permitting to discover disposition of adaptation breakings. Eight functional patterns of circulatory system reaction on physical loading were uncovered. Developing method allows reveal people with heightened risk of sudden breakings of homodynamic, accomplished control of functional coaching of students.

Key words. Functional test, breaking of adaptation, hemodynamic, students, evaluation method.

Стаття надійшла до редколегії 18.10.2015 p.

\author{
Марія Бондаренко (Рассомагіна), \\ Олександр Бондаренко, \\ Вікторія Кравченко, \\ Микола Макарчук
}

\title{
ЕЕГ аналіз розподілу уваги в лівшів та правшів при проходженні емоційного Струп-тесту на фоні пред'явлення зображень IAPS
}

Оцінювали спектральну потужність та коефіцієнт когерентності основних ритмів ЕЕГ (тета-, альфа-, бетанизькочастотний, бета-високочастотний) під час емоційного Струп-тесту на фоні зображень IAPS у лівшів та правшів із відкритим домінантним і недомінантним оком.

Ключові слова: IAPS, емоційний Струп-тест, домінантне око, недомінантне око.

Постановка наукової проблеми та ї̈ значення. У сучасному світі новітніх технологій масив інформації часто перевантажує органи чуття людини, потік даних є надзвичайно потужним та в рази більшим, ніж це було бодай 10 років тому. Намагаючись утримати рівновагу, гомеостаз і продуктивність протягом робочого дня, людський мозок користується свідомим (довільною) та підсвідомим (мимовільною) фільтром (увагою), щоб нерелевантна ситуація інформації не навантажувала операційну пам' ять. Водночас на сьогодні відомо, що будь-які емоційні стимули, чи то слова [1, 2], чи то картинки [3] спричиняють мимовільне зміщення фокусу уваги. Якщо індивід звертає увагу на емоційні стимули, нерідко вони здатні викликати певні емоції.

Низка нейропсихологічних досліджень засвідчила ЕЕГ кореляти емоцій. Ці особливості ЕЕГ у цілому можна помістити в один із двох доменів: часовий та частотний [4]. У часовому домені йдеться про пов'язані з подією викликані потенціали, а в частотному - про спектральну потужність у різних частотних діапазонах, що залучені в розвиток та підтримку емоційного стану. Спектральна потужність альфа-ритму змінюється залежно від валентності стимулу [5] або під час переживання дискретних емоцій, таких як щастя, печаль і страх [6]. Зокрема, фронтальна асиметрія альфа-ритму

() Бондаренко (Рассомагіна) М., Бондаренко О., Кравченко В., Макарчук М., 2015 